\title{
100 jaar vrouwenkiesrecht in Nederland?
}

\author{
Een historische toevoeging aan het sprookje van politieke \\ gelijkheid
}

Devika Partiman *

Er bestaat niet zoiets als honderd jaar vrouwenkiesrecht in Nederland. In 2019 vonden er door heel Nederland evenementen, tentoonstellingen en festiviteiten plaats om het heugelijke feit te vieren dat Nederlandse vrouwen nu honderd jaar naar de stembus mogen. En in 1919 veranderde de Kieswet inderdaad; in dit deel van Nederland verkregen vrouwen eindelijk het langverwachte recht om naar de stembus te gaan. Maar niet alle Nederlandse vrouwen mochten vanaf toen stemmen. Nederland was destijds nog koloniaal overheerser van de overzeese gebieden Nederlands-Indië, Suriname en de Nederlandse Antillen (Aruba, Bonaire, Curaçao, Saba, Sint-Eustatius en Sint-Maarten), en voor de vrouwen (en veel mannen) in deze delen van het koninkrijk veranderde er in 1919 helemaal niets. Alleen de koloniale, mannelijke, witte elite had hier stemrecht, en dat zou voorlopig zo blijven. In dit stuk neem ik je mee in een meer complete vertelling over het vrouwenkiesrecht.

\section{De eerste stappen naar inclusief kiesrecht}

De eerste verandering vond plaats in 1937, toen op Suriname en de Nederlandse Antillen het kiesrecht uitgebreid werd met census- en capaciteitskiesrecht. Censuskiesrecht betekende dat kiezers een bepaald minimumbedrag aan belasting moesten betalen om te mogen stemmen. Capaciteitskiesrecht betreft het stellen van bepaalde capaciteitseisen aan kiezers, zoals dat zij de lagere school moesten hebben voltooid. Op Curaçao werd het bestaande censuskiesrecht uitgebreid met beperkt capaciteitskiesrecht; vrouwen die aan de eisen voldeden en 25 jaar of ouder waren, kregen passief kiesrecht (het recht om verkozen te worden). Ook in Suriname werden de Koloniale Staten voortaan op grond van census- en capaciteitskiesrecht gekozen. Grace Schneiders-Howard werd in 1938 daardoor verkozen als eerste vrouw in de Koloniale Staten van Suriname. Deze uitbreiding van de Kieswet in Suriname en Curaçao kwam, gezien de eisen, vooral ten goede aan de elite van de witte bevolking. In Nederlands-Indië kregen vrouwen in 1938 passief kiesrecht, wederom op basis van census- en capaciteitskiesrecht. Dit gaf de groep vrouwen die behoorden tot de Nederlandse elite, de Indonesische elite en de elite van 'Vreemde Oosterlingen' (zoals de Chinese bevolking die er woonde) het recht zich verkiesbaar te stellen.

* Devika Partiman is voorzitter van de Stichting Stem op een Vrouw en bestuurslid van de Stichting Nederland Wordt Beter. 
In 1945 verklaarde Indonesië zich onafhankelijk van Nederland. President Soekarno en de regering verschaften de bevolking voortaan het algemeen kiesrecht. Drie jaar later, in 1948, werd het algemeen kiesrecht ingevoerd in de Nederlandse Antillen. Veel geschiedschrijving vertelt dat in 1948 ook in Suriname het algemeen kiesrecht werd ingevoerd. Echter, dit zogenaamde algemeen kiesrecht gold niet voor de marrons en de inheemse bevolking. De marrons zijn afstammelingen van de tot slaaf gemaakte Afrikaanse bevolking van Suriname, wier voorouders het lukte om van de wrede behandeling op de plantages te vluchten. De gevluchte, tot slaaf gemaakten vestigden zich in het regenwoud van Suriname, waar zij zich verscholen voor de slavenhouders en eigen dorpen stichtten. Kortom de Nederlandse kolonisator weigerde de oorspronkelijke bevolking van Suriname en de afstammelingen van de gevluchte, tot slaaf gemaakte bevolking een stem te geven. Het zou nog vijftien jaar duren voordat in Suriname écht algemeen kiesrecht ingevoerd, in 1963.

Willen we in Nederland een historisch juiste viering organiseren van honderd jaar vrouwenkiesrecht, dan zullen we dus ten minste moeten wachten tot het jaar 2063.

\section{$\mathrm{Na}$ 1963: de uitsluiting gaat verder}

Gedurende de jaren zestig en zeventig werden Nederland en de rest van Europa langzaamaan gedwongen om hun koloniën af te staan en/of meer onafhankelijkheid te bieden. Hierdoor kwamen mensen die in de koloniën hadden gewoond vaker in Nederland studeren en werken (denk aan voormalige inwoners van Suriname, de Nederlandse Antillen, Indonesië en de Molukken), en door de groeiende economie wierf Nederland ook gastarbeiders uit onder meer Marokko en Turkije.

Het algemeen kiesrecht bleek niet voor al die mensen toegankelijk. Zoals de geschiedenis van de Kieswet doordrenkt is van het uitsluiten van mensen van kleur en uit voormalige koloniën, zo ging het heden verder. Deze groepen inwoners van Nederland, die toen nog 'allochtonen' genoemd werden, verkregen pas in 1985 lokaal stemrecht. Met name de inzet van de Molukse bevolking leidde ertoe dat mensen die zelf of wier ouders niet in Nederland waren geboren, toegang kregen tot stemrecht op gemeenteniveau. In 1998 promoveerde Dirk Jacobs op een onderzoek naar de uitsluiting van de kieswetten in Nederland en België. ${ }^{1}$ Ten tijde dat zijn onderzoek uitkwam, mocht maar liefst 5 procent van de volwassen bevolking in Nederland zich niet verder dan op gemeentelijk niveau politiek uiten. In een interview met de Volkskrant zei hij daarover: 'Europese vreemdelingen in Nederland en België mogen stemmen, maar Marokkaanse en Turkse bewoners, die toch ook belasting betalen, mogen dat niet. Zij zijn tweederangsburgers. Maar de traditionele koppeling van rechten aan het staatsburgerschap is voorbijgestreefd. Dat stamt uit de tijd van de Franse revolutie. We zitten in een veel dynamischer wereld, een wereld van migratie. We zijn twee eeuwen verder en moeten traditionele opvattingen durven loslaten.' 
Ook nu nog zijn er in Nederland groepen mensen met beperkt of geen stemrecht.

${ }^{3}$ Zo mogen ongedocumenteerde mensen en mensen zonder Nederlandse nationaliteit die korter dan vijf jaar in Nederland wonen niet stemmen. Mensen zonder Nederlandse nationaliteit die langer dan vijf jaar in Nederland wonen, en Molukse Nederlanders die hier geboren zijn maar wiens ouders nooit de Nederlandse nationaliteit hebben aangenomen (en wier kinderen tot 1991 daardoor een zogenaamd 'faciliteitenpaspoort' kregen ${ }^{4}$ ), mogen slechts op gemeentelijk niveau stemmen.

Bovendien mogen inwoners van Bonaire, Sint-Eustatius en Saba met de Nederlandse nationaliteit pas sinds 2018 (!) stemmen voor de provinciale statenverkiezingen. Bewoners zonder Nederlandse nationaliteit mogen tot op de dag van vandaag niet stemmen voor de provinciale staten (en dus voor de Eerste Kamer), ondanks dat hun eilanden een bijzondere gemeente van Nederland zijn en dat er daarom wel degelijk over hen wordt besloten. Wel stemmen inwoners van de eilanden - ongeacht de Nederlandse nationaliteit - op het eigen eiland op de eilandraad, vergelijkbaar met de gemeenteraad.

\section{Inclusieve geschiedenis}

Het moge duidelijk zijn: die 'honderd jaar vrouwenkiesrecht'-viering hadden we wel over mogen slaan. En ook de focus op gender is binnen de historie van het kiesrecht te beperkend wanneer we over politiek gelijke rechten willen praten. Onze politici behoren al sinds het begin van de democratie in Nederland tot dezelfde norm: man (en later ook vrouw), wit, hetero, universitair opgeleid, niet uit een arm milieu, zonder fysieke beperking. Het huidige narratief over vrouwenkiesrecht, waarbij het lijkt alsof er gepraat wordt over politieke gelijkheid tussen 'alle mannen' en 'alle vrouwen', negeert de koloniale verhoudingen, alsmede het classicisme, het racisme en het seksisme die gepaard gaan met de geschiedenis van ons kiesrecht. Het vieren van 'honderd jaar vrouwenkiesrecht' schept daardoor niet alleen een onjuist beeld van de geschiedenis, maar wist ook actief de geschiedenis en ervaring van vele Nederlanders uit. Laat dit stuk daarom een bijdrage zijn aan een nieuw narratief: de ware geschiedenis van kiesrecht in Nederland.

\section{Kom zelf in actie}

Om van de politiek een plek te maken waarin iedereen zich thuis voelt en gepresenteerd kan zien, is er een aantal zaken die je kunt doen. De makkelijkste manier is om slim te stemmen, via de voorkeurstem. Dit werkt als volgt: veel kiezers die 'standaard' op vrouwen stemmen, brengen hun stem uit op de eerste vrouw op de lijst. Dat is sympathiek, maar helpt niet om daadwerkelijk meer vrouwen de politiek in te krijgen. Deze eerste vrouw komt namelijk vaak dankzij haar hoge positie op de kieslijst ook zónder die voorkeurstem al in de politiek. Kijk daarom niet alleen naar positie op de lijst, maar ook naar de peilingen: hoeveel zetels krijgt een 
partij naar verwachting ongeveer? Zijn er geen peilingen, ga dan af op hoeveel zetels de partij nu heeft. En nieuwe partijen starten vaak klein. Stem vervolgens op een vrouw die op een positie op de lijst staat rond het gepeilde aantal zetels, of die er net buiten valt. Zij heeft jouw stem hard nodig om toch verkozen te worden. Zelf zet ik me via de stichting Stem op een Vrouw in voor het verspreiden van deze stemtactiek. Mede dankzij onze stemcampagnes werden in 2017 drie extra vrouwen verkozen in de Tweede Kamer, in 2018 tientallen vrouwen in gemeenteraden door heel Nederland, in 201942 extra vrouwen in de provinciale staten en het waterschap, en nog eens drie vrouwen extra in de Nederlandse delegatie het Europees Parlement. Die delegatie bestaat sindsdien voor het eerst voor de helft uit vrouwen.

Verzeker je er wel van dat jouw kandidaat ook bij jouw standpunten past. Je vindt rond verkiezingstijd alle verkiesbare partijen en informatie over de kandidaten op www.stemopeenvrouw.com. Zo kun je kijken welke kandidaat het best bij jou past. En deze tactiek werkt natuurlijk niet alleen voor vrouwen, maar voor alle ondergerepresenteerde groepen.

Ten tweede is het belangrijk om meisjes en vrouwen aan te moedigen om politiek actief te worden. Vergeet ook hierbij niet om te denken aan álle meisjes en vrouwen, inclusief degenen die behoren tot ondergerepresenteerde groepen zoals vrouwen van kleur, transvrouwen, vrouwen met een beperking en vrouwen uit armere milieus. Onderzoek toont aan dat vrouwen graag persoonlijk benaderd worden met de vraag of zij actief willen worden, ${ }^{5}$ dus jouw steuntje in de rug kan echt een verschil maken.

Het is tijd voor een politiek waarin iedereen zich kan herkennen. Om iedereen mee te krijgen in het belang daarvan, moeten we beginnen bij de verhalen die we vertellen over het kiesrecht. Pas wanneer we erkennen dat uitsluiting een belangrijke component is van onze politieke geschiedenis, kunnen we het gebrek aan representatie eerlijk bespreken én aanpakken.

\section{Noten}

1 https://books.google.nl/books?

$\mathrm{id}=\mathrm{kcr} 9 \mathrm{GBC}$ leQC\&lpg=PA289\&ots=4OARGUlKAN\&dq=dirk\%20jacobs

\%20proefschrift\&hl=nl\&pg=PR5\#v=onepage\&q=dirk\%20jacobs

\%20proefschrift\&f=false

2 Zie ook www.volkskrant.nl/mensen/allochtonen-moeten-op-alle-niveaus-stemrechtkrijgen b5e24b9e/.

3 Een uitzondering hierop zijn de waterschapsverkiezingen. Iedereen die waterschapsbelasting betaalt, mag stemmen bij deze verkiezingen.

4 Zie ook.www.rvig.nl/actueel/nieuws/2017/07/04/informatieverstrekking-bijaanvragen-van-reisdocumenten-door-molukkers.

5 https://atria.nl/nieuws-publicaties/internationaal-nationaal/vrouwen-in-de-politiek/ onderzoeksrapport-vrouwenstemmen-in-de-raad/. 